\title{
NON-HODGKIN'S LYMPHOMAS
}

\section{8}

Autologous transplantation of haematopoietic cells in high grade NHL

B.Afanasiev, A.Zaritskey, L.Zoubarovskaya,

N.Medwedeva, J. Alexeeva

Medical University, Clinical Centre for Advanced

Medical Technologies, St. Petersburg, Russia

Aim comparison of conventional treatment of high grade NHL with early intensification by autologous haematopoetic cell transplantation.

Patients and methods : 36 patients with chemosensitive disease were included in the study. According to gender and age two groups were comparable. Patients were treated with conventional protocols (Hoelzer 1989,Kantarjian 1990) or with our modification: CHOP-CHOP followed by DexaBeam and haematopoietic cell transplantation. Some of them were treated with conventional protocols followed(or not) by haematopoietic cell transplantation.

Results: Overall survival appeared to be supeerior in transplanted patients $(\mathrm{p}=0.014)$.

Overall survival tends to be better in CHOPDexaBeam-ABMT in comparison to conventional chemotherapy regimens.

Conclusions.Early haematopoietic cell transplantation in chemosensitive NHL (in first remission or before it) is superior to conventional long-lasting chemotherapy.

\section{9}

IS THERE AN EFFECT OF GRAFT VERSUS HOST DISEASE ON RELAPSE IN PATIENTS WITH LYMPHOMA UNDERGOING ALLOGENEIC HEMOPOIETIC STEM CELL TRANSPLANTS ?

A.Bacigalupo, G Taghipur, C.Ruiz, N. Schmitz for the Lymphoma WP.

Reports on the effect of GVHD on relapse in patients with malignant lymphoma undergoing allogeneic HSCT have been scarse and based on very small numbers of patients.

We have studied 593 intermediate/high grade non Hodgkin lymphoma (NHL) who received an allograft and were registered in the EBMT Lymphoma Registry. We subdivided patients in 4 categories : (group 1) intermediate/high grade grafted in $1^{\text {st }} \mathrm{CR}(\mathrm{n}=73)$; (group 2) intermediate/high grade grafted beyond $1^{\text {st }} C R(n=260) ;($ group3) lymphoblastic (LBL)/Burkitt grafted in $1^{\text {st }} \mathrm{CR}(n=109)$; LBL/Burkitt grafted beyond $1^{\text {st }} C R$ ( $n=151$ ). Overall 400 patients developed acute GVHD grade $0-1$ and 193 aGvHD grade II-IV: the actuarial risk of relapse at 4 years for patients with aGvHD grade $0-1$ or II-IV was as follows :

intermediate/high grade $1^{\text {st }} C R 24 \%$ vs $27 \%(p=0.7)$;

intermediate/high grade $>1^{\text {st }}$ CR $35 \%$ vs $28 \%(p=0.2)$

LBL/Burkitt $1^{\text {st }}$ CR $25 \%$ vs $7 \%(p=0.2)$;

LBL/Burkitt $>1^{\text {st }}$ CR $56 \%$ vs $48 \%(p=0.2)$

368 patients $(62 \%)$ were alive at day +100 and therefore eligible to develop chronic GVHD (cGVHD): 188 (51\%) developed no CGVHD, whereas 180 developed CGVHD. The actuarial risk of relapse at 4 years for patients stratified according to CGvHD was as follows:

intermediate/high grade $1{ }^{\text {st }} \mathrm{CR} \quad(n=49) 29 \%$ vs $18 \%(p=0.5)$

intermediate/high grade $>1^{\text {st }} C R(n=153) 34 \%$ vs $27 \% \%(p=0.2)$

LBL/Burkitt $1^{\text {st }} C R(n=90) 30 \%$ vs $9 \%(p=0.06)$

LBL/Burkitt $>1^{\text {st }}$ CR $(n=76) 47 \%$ vs $37 \%(p=0.1)$.

We have also analyzed 92 patients with Hodgkin's disease (HD) allografted beyond $1^{\text {st }} \mathrm{CR}$ : the risk of relapse at 4 years was $55 \%$ vs $53 \%(p=0.3)$ if stratified for acute GvHD (no/yes) and $37 \%$ vs $60 \%$ $(p=0.8)$ when stratified for chronic GvHD (no/yes).

This study suggests that acute and chronic GvHD have little impact on relapse after allogeneic HSCT for Lymphoma, with the exception perhaps of CGvHD in LBLBurkitts Ivmohoma alloarafted in $1^{\text {st }} \mathrm{CR}$. 
ALLOGENEIC STEM CELL TRANSPLANTATION (AlloSCT) IN PATIENTS WITH LYMPHOMA RELAPSING AFTER AUTOLOGOUS SCT (AutoSCT)

Vinko Bogdanić, Igor Auer, Damir Nemet, Mirando Mrsić, Boris Labar. Division of Hematology, Department of Internal Medicine, University Hospital Center Rebro, Zagreb, Croatia.

We report our experience in six patients with aggressive non-Hodgkin lymphoma (NHL).Patients were between 6 and 47 years old. Two had anaplastic large cell and one each medium grade follicular, $\mathrm{B}$ diffuse large cell, Burkitt-like and B lymphoblastic lymphoma. Four were autografted with primary resistant disease after first line of chemotherapy, one in first remission after second line of chemotherapy, and one in second remission,between 8 and 15 months after diagnosis. Three received bone marrow (BM), two peripheral blood, and one both sourcesof autoSCT. All were conditioned with BEAM, all engrafted.Two patients with bulky mediastinal disease received nediastinal irradiation posttransplant. Remission duration after autoSCT was between 3 and 13 months. AlloSCT was performed 6 to 27 months after autoSCT, at that time all patients had active disease.Total body irradiation and cyclophosphamide were used for conditioning. Five patients received BM from HLA-compatible sibilings, while one received a haploidentical umbilical cord blood transplant (UCBT) from a sibling. The former received cyclosporine and methotrexate, and the latter patient cyclosporine only for graft-versus-host disease prevention. All had severe mucosities;other side effects were within expected limits.The patient receiving UCBT died early, with active dicease and without signs of engraftment. One patient with BM alloSCT is too early for evaluation, the remaining five engrafted within 30 days. None had severe GvHD, 2 had GvHD grade I and 2 grade II. Two patients relapsed, 3 and 5 months after alloSCT while 2 are in clinical remission with a follow-up of 7 and 12 months. AlloSCT from HLA-compatible sibiling donors is feasible and reasonably well tolerated in patients who relapse after autoSCT.Efficacy of this approach remains to be determined, but some patients may achieve meaningfully durable remissions.

\section{2}

TREATMENT OF RELAPSED ANGIOIMMUNOBLASTIC LYMPHADENOPATHY WTTH DYSPROTEINAEMIA BY HIGH-DOSE CHEMOTHERAPY AND AUTOLOGOUS STEM CELL TRANSPLANTATION

J. Chemnitz, Ch. Scheid, A. Draube, A. Schulz, M. Fuchs, V. Diehl, D. Söhngen

I. Dept. of Medicine, University of Cologne, Germany

Angioimmunoblastic lymphadenopathy with dysproteinaemia (AILD) is a rare lymphoproliferative disorder characterized by diffuse lymphadenopathy, fever, hepatosplenomegaly, haemolytic anaemia and polyclonal hypergammaglobulinaemia. Treatment of AILD has been unsatisfactory, with approximately $25 \%$ of patients achieving complete and sustained remission after combined chemotherapy. So far there are no generally accepted therapy schedules for first or second line treatment of AILD.

A 52-year-old male patient was diagnosed as AILD in December 1996. No complete remission was achieved by 4 cycles of CHOP-chemotherapy neither by one cycle of DexaBEAM. Subsequently the patient was treated with high-dose etoposide $(45 \mathrm{mg} / \mathrm{kg}$ ) and total body irradiation (12 Gy) followed by autologous stem cell transplantation (ASCT) in July 1997. After this treatment the patient has reached a sustained complete remission for 15 months until now.

There is a single report on successful treatment of relapsed AILD with high-dose chemotherapy using etoposide, cyclophosphamide and BCNU followed by ASCT. In view of lacking standard therapy strategies an agressive chemotherapy regimen with ASCT is a promising concept to improve remission rates and disease-free survival.
HIGH DOSE THERAPY WITH AUTOLOGOUS STEM CELL SUPPORT IN 366 PATIENTS WITH CARGE CELL LYMPHOMA H RETROSPECTIVE ALANYSIS OF THE GEL/TAMO SPANISH COOPERATIVE GROUP.

MD Caballero*, J García-Laraña, M Gandarillas**, J Marín, JJ Lahuerta, R Arranz, V Rubio, JG García-Conde, J Zuazu, L Vázquez*, E Montserrat, A Grañena, MA Sanz, R Mataix, J Maldonado, J Rifón, J. Sierra, D Carrera, JM Moraleda, JC García, E Conde**. Servicios de Hematología : *Clínico Salamanca, Ramon y Cajal Madrid, **Valdecilla Santander, NS. De Aránzazu San Sebastian, 12 de Octubre, La Princesa Madrid, Jerez de la Frontera, Clinic Valencia, Vall d'Hebron, Clinic y Duran Reynals Barcelona, La Fe Valencia, NS del Pino Las Palmas, C Haya Málaga, Clinica Navarra, S Creu i San Pau Barcelona, General Oviedo, General Murcia, Cruces Bilbao.

Three hundred and sixty six patients with large cell lymphome (LCL) centroblastic (262) or inmunoblastic (104) received an autologous stem cell transplant (ASCT) between 1987 and 1998 and were included in the GEL/TAMO Spanish registry. $80 \%$ of patients had a B-cell and $20 \%$ T-cell phenotype. At diagnosis $258 \mathrm{p} \mathrm{(} 71 \%$ ) were in stager III-IV; bone marrow was involved in $21 \%$ of cases and 216 ( $59 \%$ ) had extrenodal disease. $38 \%$ of the groups displayed a IP intermediate high-high. At transplantation 192 patients were in first ( 129 cases) or subsegment (63 cases) CR, 130 patients had sensitive disease (SD) and 44 patients resistant disease (RD). Condition regimen included Cy+TBI $(45 \mathrm{p})$ $\operatorname{BEAM}(134 \mathrm{p}), \operatorname{BEAC}(130 \mathrm{p}), \mathrm{CBV}(36 \mathrm{p})$ and others ( $21 \mathrm{p})$.

Transplant related mortality was $8 \%$ in patients transplanted with sensitive disease and $25 \%$ for the group with resistant lymphome. Response to transplant (evaluated 3 months after trx) showed that $76 \%$ of patients with sensitive disease and $16 \%$ of those with resistant disease achieved / mantained CR. Estimated overall survival (OS) at 6 years is $51 \%$ for the whole group of patients. Upon analizing the outcome according to situation of the disease at transplant, OS and relapse free survival (RFS) are significantly better for patients transplanted on $1^{\text {st }}$ $\mathrm{CR}\left(71 \%\right.$ and $76 \%$ respectively) as compared with patients in $2^{\text {nd }} \mathrm{CR}(55 \%$ and $50 \%$ ) SD ( $46 \%$ and $59 \%$ ) and resistant disease ( $4 \%$ and $38 \%$ respectively) $(p=0.0003)$. Although several variable at transplant influence $O S$ in univariate analysis (ECOG, B symptoms, bulking disease, high LDH level, extranodal disease $(>2)$, IPI and situation at transplant $(\mathrm{p}<0.001)$, only the pre-transplant situation remained as an independent prognostic factor in the multivariate analysis. In conclusion, autologous transplant is useful in patients with LCL and sensitive disease, other strategies need to be investigated for resistant lymphoma. The very good results obtained with patients transplanted on first CR need to be confirmed in prospective randomized trials.

\section{3}

BONE MARROW TRANSPLANTATION (BMT) IN HIGHGRADE MA!IIGNANT NON-HODGKIN'S LYMPHOMAS. B. Choufi, H. Curé, J.O. Bay, Ph. Travade, X. Durando, C. Glénat, M. Legros ${ }^{\dagger}$, R. Plagne. Centre Jean PERRiN, 58 rue Montalemioert, 63011 Clermont-Ferrand Cedex 1, France.

Allogeneic bone marrow transpiantation is a therapeutic strategy for high-grade non-Hodgkin's lymphomas that have high-risk of relapse. The therapeutic effect is related to both conditioning and GVH. From August 1987 tc July 1996, we grafted 7 patients (pts) from geno-identical HLA-compatib!e donors without T-cell depletion. Median age of pts : 30 (1739). PS > $2: 4 / 7$ pts ; stage IV : $7 / 7$ pts, increased LDH : $7 / 7$ pts. Histology : 1 transformed low-grade, 2 lymphoblastic $T$, 1 Burkitt, 1 immunoblastic $T, 1$ centroblastic B. Five received more than 2 therapeutic procedures including 2 autologous bone marrow transpiantations. Status before transplantation: 2 failures, $1 \mathrm{PR}, 4 \mathrm{CR}$. The conditioning consisted of: $\mathrm{TBI}+\mathrm{CPH}(\mathrm{N}=3) ; \mathrm{TBI}+\mathrm{CPH}+\mathrm{VP} 16(\mathrm{~N}=$ 4). CSA/MTX was used for GVH-homogeneous disease prevention. There were 3 immediate post-transplant deaths : 2 pts initially autografted who were in progression at the time of allogeneic BMT. Causes of death : 1 venoocclusive disease, 1 disease progression and $1 \mathrm{pt}$ deceased of septic shock and digestive GVH. The 4 survivors experienced cutaneous GVH grade 2, without chronicity, and durable CR (interval: 3.5 to 11 years). These pts received initially only 1 therapeutic procedure and were grafted after CR (average deadline : 5 months after diagnosis). Theiefore, the geno-identical allograft seems quite effective in these cases. Mortality related to toxicity is currently well contro!!ed. The procedure being expensive, the indication should be closely followed: young pts, in CR or good $P R$, to minimize iatrogenic toxicity as soon as possible. 
VALUE OF AUTOLOGOUS STEM CELL TRANSPLANTATION (ASCT) WITH PURGED STEM CELLS AS FIRST LINE THERAPY OF FOLLICULAR LYMPHOMA WITH HIGH TUMOR BURDEN.

Ph. Colombat, P. Cornillet, Ch. Foussard, J.Y. Cahn, M. Escoffre-Barbe, H. Maisonneuve, J.M. Tourani, M. Delain, C. Kootz, N. Milpied for the GOELAMS GROUP Haematology Department - CHU BRETONNEAU TOURS - FRANCE

From 01/92 to 03/94 a phase II study was conducted by the GOELAMS Group to evaluate the value of purged stem cell transplantation in the treatment of follicular lymphoma with high tumor burden. Since $04 / 94$ a phase III randomised study evaluates the same approach in comparison with conventional therapy with interferon.

We will present here the results of all the patients included before 07/96 in the phase II study and in the ASCT arm of the phase III study. All the patients were follicular lymphoma with high tumor burden defined by at least one of the following criteria : presence of B symptoms, nodal or extranodal site $>7 \mathrm{cms}$, complications as compression or serious effusion, massive splenomegaly, cytopenia, increase of LDH or $\beta 2$ microglobulin levels.

Therapeutic program was 3 courses of conventional chemotherapy (VCAP) associating Doxorubicin $80 \mathrm{mg} / \mathrm{m}^{2}$ d2, Vindesine $3 \mathrm{mg} / \mathrm{m}^{2} \mathrm{~d} 1$ and $\mathrm{d} 5$, Cyclophosphamide $1,5 \mathrm{~g} / \mathrm{m}^{2} \mathrm{~d} 2$ and Prednisone $80 \mathrm{mg} / \mathrm{m}^{2} /$ day d 1 to $\mathrm{d} 5$. If complete remission or very good partial remission were obtained, stem cells were harvested and stem cell transplantation was performed after one course of IM-VP 16 (Ifosfamide, Methotrexate, Etoposide). If an incomplete response was observed, the patients received two courses of DHAP (Dexamethasone, ARAC and Cisplatinum) as salvage regimen. Conditioning regimen was Total Body Irradiation and Cyclophosphamide $(120 \mathrm{mg} / \mathrm{kg})$.

Fifty one patients are analysed ( 29 men and 22 women). Median age was 44 years (range 27-60). Histology was follicular predominantly small cell in 14 cases, follicular mixed in 33 cases and follicular predominantly large cell in 4 cases.

Autologous stem cell transplantation was performed in 46 cases because progression or insufficient response to chemotherapy $(n=4)$ or refusal $(n=1)$ Stem cell purging was negative selection in 32 cases (immunological purging with complement : 20 cases, immunomagnetic purging : 12 cases) and $\mathrm{CD} 34+$ positive selection in 14 cases (Peripheral Blood Stem cells : 13 cases). Two toxic deaths were observed.

With a median follow up of 56 months the event free survival for all the patients is $62 \%$.

Evaluation of the minimal disease for the phase II patients will be presented.

\section{6}

AUTOLOGOUS STEM CELL TRANSPLANTATION (ASCT) FOR FOLLICULAR LYMPHOMA (FL). THE EXPERIENCE OF THE GEL/TAMO SPANISH COOPERATIVE GROUP. JJ. Lahuerta, E. Conde, J. Sierra, R. Arranz, E. Montserrat, D. Caballero, J. García-Conde, M Gandarillas, V. Rubio, J. Bueno, A. Grañena, L.G. Ponte, J. García-Laraña, MJ. Vidal, D.Carrera, D. Rubio-Felix, JM. Moraleda, J. Maldonado, F Hernández, P. Vivancos, M. Gutierrez, MR. Varela, R. Bornstein, A Zubizarreta. Servicios de Hematología-Hemoterapia de Santander, Madrid, Barcelona, Salamanca, Valencia, Jerez de la Frontera, San Sebastián, Oviedo, Zaragoza, Murcia, Málaga y La Coruña. Spain

From June 1987 to December 1997, 210 pts. with FL underwent ASCT. The $\mathrm{n}^{\circ}$ of cases in each histologic group was 61 follicular small cleaved cell, 121 follicular mixed and 28 follicular large cell. Median age was 46 years (range 23 to 68) and 93 pts. were male. Most pts. transplanted in 1st. CR had bad prognostic criteria. Pts. were treated as first line therapy with CVP (49), CHOP (135) and other chemotherapy regimens (26). Disease status at ASCT was first CR in 53 pts., second CR in 46 pts., chemosensitive disease (SD) in 100 pts. and chemoresistant disease (RD) in 11 pts. Stem cells for engraftment were obtained from bone marrow in 78 cases and from peripheral blood in the remaining 132 In order to mobilize peripheral blood stem cells 76 pts. received G-CSF and 56 chemotherapy plus G-CSF. The median number of CD34+ cells infused was $3.12 \times 10^{6} / \mathrm{kg}$ (range 1.1 to 37.3 ). The conditioning regimen was cyclophosphamide and total body irradiation in 53 pts. The remaining 157 pts. were treated with BEAC (84 pts.), BEAM (53), CBV (12) o BUCY (2). Response after transplantation was CR in 172 pts. (82\%), PR in $17(8 \%)$ and failure to treatment $10(5 \%)$. The remaining $11 \mathrm{pts.}(5 \%)$ were not evaluable because they died before the 21 st day post-ASCT. The median follow-up of the disease-free pts. was 26 months. Thirty-seven pts. have relapsed, the median time to relapse being 13 months (range 2 to 65 ) Estimated 10-year OS and DFS for all 210 pts. was $50 \%$ and $43 \%$, respectively, with a median DFS of 20 months. The actuarial probability of relapse for 172 evaluable pts. was $41 \%$ at 10 years. Multivariate analysis showed that disease status at ASCT $(\mathrm{p}<0.0001)$ and IPI at diagnosis $(p=0.006)$ were the only variables that retained their independent predictive value for OS. In the multivariate analysis, disease status at ASCT $(p=0.003)$ and IPI at diagnosis $(p=0.02)$ retained significance for relapse. The overall mortality was $18 \%$ (36 of 210 ). Sixteen patients $(8 \%)$ died because of lymphoma and the remaining $20(10 \%)$ as a result of toxicity.Toxic mortality in 1 st. CR was $4 \%$. In conclusion, this large series shows that prognostic factors at diagnosis as well as disease status and PS at transplant markedly influence the outcome of patients with FL submitted to ASCT.
AUTOLOGOUS STEM CELL TRANSPLANTATION (ASCT) FOR MANTLE CELL LYMPHOMA (MCL). THE EXPERIENCE OF THE GEL/TAMO SPANISH COOPERATIVE GROUP. E Conde F. Bosch, R. Arranz, D. Caballero, JJ. Lahuerta, J. García-Conde, J. Sierra, M. Gandarillas, JM. Fernández-Rañada, A. León, A. Iriondo, J. San Miguel, J. Besalduch, A. Grañena, D. Carrera, J. Marín, J. Maldonado, JM. Moraleda, D. Rubio-Felix, J. Díaz Mediavilla, J. Zuazu, P. Vivancos, L. Palomera, MA. Piris, E. Montserrat. Servicios de Hematología-Hemoterapia de Santander, Barcelona, Madrid, Salamanca, Valencia, Jerez de la Frontera, Mallorca, Oviedo, San Sebastián, Málaga, Murcia, Zaragoza y Servicio de Anatomía Patológica de Toledo. Spain

From December 1988 to December 1997, 55 pts. with MCL underwent ASCT. Median age was 49 years (range 21 to 64 ) and 39 patients were male. Patients were treated as first line therapy with CHOP $(35$ patients), CVP (4), PROMACE-CytaBOM (8), Hyper-CVAD (6) and DHAP (2). Disease status at ASCT was first CR in 15 patients, second CR in 9 patients, chemosensitive disease (SD) in 28 patients and chemoresistant disease (RD) in 3 patients. Stem cells for engraftment were obtained from. bone marrow in 10 cases or from peripheral blood in the remaining 45 . In order to mobilize peripheral blood stem cells (PBSC) 29 patients received G-CSF and the remaining 16 chemotherapy plus G-CSF. The median number of CD34+ cells infused was $3.29 \times 10^{6} / \mathrm{kg}$ (range 1.2 to 33.8 ). The conditioning regimen was cyclophosphamide and total body irradiation in 12 patients. The remaining 43 patients were treated with BEAC (19 patients), BEAM (16 patients), CBV (6 patients) or BUCY (2 patients) regimens. Response after transplantation was CR in 44 patients $(80 \%)$, PR in $7(13 \%)$, failure to treatment $2(3.5 \%)$. The other 2 patients $(3.5 \%)$ were not evaluable because they died before the 21 st day post-ASCT. The median follow-up of the disease-free patients was 17 months. Sixteen patients have relapsed, the median time to relapses being 12 months (range 3 to 48). Estimated 9-year OS and DFS for all 55 patients was $58 \%$ and $26 \%$, respectively, with a median DFS of 16 months. The actuarial probability of relapse for 44 evaluable patients was $67 \%$ at 9 years. The major prognostic parameter associated with a short DFS was disease status at ASCT $\mathrm{p}=0.04$. No predictive factor for a higher probability of relapse was found. Median time to granulocyte $\left(\geq 0.5 \times 10^{\circ} / 1\right)$ and stable platelet $\left(\geq 20 \times 10^{\circ} / 1\right)$ recovery was 12 and 14 days, respectively. Median time to discharge was 19 days. The overall mortality was $29 \%$ (16 of 55$)$. Toxic mortality was $5 \%$ and mortality due to lymphoma was $24 \%$. No patients transplanted in first CR died due to toxicity. In conclusion, our results show a high remission rate with a significant relapse rate for patients with MCL treated with ASCT.

\section{7}

ALLOGENEIC STEM CELL TRANSPLANTATION FOR LYMPHOPROLIFERATIVE DISEASE USING BEAM-CAMPATH CONDITIONING: AN EFFECTIVE REGIME WITH LOW PROCEDURE-RELATED TOXICITY. Cull GM, Haynes AP, Byrne JL, Carter GI, Miflin G, Hale G, Waldmann $H$ and Russell NH. Division of Haematology, School of Clinical and Laboratory Sciences, University of Nottingham and Sir William Dunn School of Pathology, University of Oxford, UK

The BEAM regime has been widely used as conditioning therapy for patients with lymphoproliferative disease undergoing high-dose chemotherapy and autologous stem cell transplantation. In an attempt to reduce the high procedure-related mortality associated with allogeneic transplantation in lymphoma we have used BEAM as low-intensity conditioning therapy for 9 patients (median age 48 yrs) undergoing transplantation for lymphoma $(n=8)$ or myeloma $(n=1)$ from either HLA-identical $(n=7)$ or partially matched $(n=2)$ sibling donors. To enhance immunosuppression and promote durable engraftment, Campath 1G was given intravenously from day -5 to -1 inclusive as additional conditioning therapy. The source of stem cells was G-CSF mobilised PBSC in 7 patients and bone marrow in 2 patients. All patients had sustained engraftment with median time to an ANC $>0.5 \times 10^{9} / \mathrm{L}$ of 19 days and platelets $>20 \times 10^{9} / \mathrm{L}$ of 24 days. Of 6 patients with informative markers, 5 had full donor chimerism and one had mixed chimerism. Immune reconstitution was not significantly different from a control group of patients receiving conventional conditioning. GVHD prophylaxis consisted of cyclosporin and methotrexate at day +1 , +3 and +6 . No patient has developed acute or chronic GVHD. One patient died at day +12 of progressive lymphoma and one patient with refractory lymphoma achieved a partial remission but relapsed and died 6 months post-transplant. The remaining 7 patients all achieved CR and remain disease free with a median follow-up of 6 months (1-22). The BEAM-Campath regimen appears a non-toxic regimen worthy of further evaluation as conditioning therapy prior to allogeneic transplantation for the lymphoproliferative disorders, particularly as the CD52 antigen recognised by Campath antibodies is expressed on lymphoma cells. 


\section{8}

Autologous stem cell transplantation in follicular lymphoma with high tumor burden : a single center experience.

M. Delain, I. Desbois, J. Domenech, C. Binet, L. Sensebé, J.P. Lamagnère, $\mathrm{Ph}$. Colombat. Tours, France.

From 1984 to 1997,38 patients with histologically proven high tumor mass follicular lymphoma (FL) received an autologous stem cell transplantation (ASCT). All the patients were FL with high tumor burden defined by at least one of the following criteria : presence of B symptoms, nodal or extranodal site $>7 \mathrm{~cm}$, complications as compression or serous effusion, massive splenomegaly or increase of $\mathrm{LDH}$. (range : 22 - 60 years). Histology was follicular predominantly small cell in 8 cases, follicular mixed in 28 cases and follicular predominantly large cell in 2 cases. At ASCT, 25 patients were in CR1 or PR1 and 13 in CR2 or PR2. Sixteen patients received unpurged graft (marrow 8, PBPC 8). Twenty two patients had purged graft (marrow 18, PBPC 4), 7 with adjusted dose of cyclophosphamide derivatives, 7 with anti B-cell monoclonal antibodies plus complement, 4 with an anti-B immunomagnetic system (Baxter), and 4 had positive selection of CD34+ cells (Baxter). All patients were conditionned with TBI followed by cytoxan (29 patients) or BEAM ( 9 patients).

Median follow-up is 69 months (range : 15 - 25 months). After ASCT, CR was achieved in 35 patients Two toxic deaths were observed. Actuarial survival at 5 years was $81 \%$ overall (OS), $72 \%$ disease-free (DFS) and $61 \%$ event-free (EFS). The effect of purging was assessed. The 5 years DFS is $72 \%$ and $71 \%(\mathrm{p}=0.48)$ for unpurged and purged patients respectively. The outcome of patients grafted in CR1 or PR1 is not different compared to more advanced patients (5 years DFS $=74 \%$ therapy to perform ASCT does not seem to modify the prognosis as compared to ASCT in first line.
There were 24 men and 14 women. Median age was 39 years versus $67 \%-p=0.68$ ). At the present time, waiting for failure of first line

\section{9}

AUTOLOGOUS STEM CELL TRANSPLANTATION AS CONSOLIDATION OF FIRST LINE RESPONSE FOR AGGRESSIVE NON HODGKIN'S LYMPHOMAS.

R. Fanin, A. Sperotto, A. Geromin, M. Cerno, R. Stocchi, F. Zaja, F. Patriarca, F. Silvestri, D. Damiani, M. Baccarani.

Chair and Division of Hematology, Dpt. of Medical and Morphological Research and Dpt. of Bone Marrow Transplantation, University Hospital, Udine, Italy.

The role of high dose chemotherapy (CHT) followed by autologous stem cell transplantation (ASCT) for patients (pts) with non Hodgkin's lymphoma $(\mathrm{NHL})$ in first remission remains controversial. Herein we report the results of a single center non-randomized trial where ASCT was employed in a group of 63 consecutive pts with NHL (No.25 diffuse large B cell lymphoma, No.15 anaplastic large cell 1 . T or null cell type, No.7 T lymphoblastic 1., No.3 peripheral T cell 1., No. 6 marginal zone 1., No.7 follicle centre 1.), at least one of the following risk factor: bulky disease, B symptoms or Ann Arbor Stage III-IV and at least a partial response (PR) after CHT (and radiotherapy -RT- on residual mediastinal mass when required). Out of $63 \mathrm{pts}, 40(63.5 \%)$ were in stage III and IV, $41(65 \%)$ had a bulky disease and $35(55.5 \%)$ had B symptoms. According to the AgeAdjusted International Prognostic Index, $14 / 63(23 \%)$ pts were in the low risk group (L), 31/63 (49\%) in the low-intermediate risk group (L-I), 9/63 $(14 \%)$ in the high-intermediate risk group (H-I), $9 / 63(14 \%)$ in the high risk group $(\mathrm{H})$. Fifty-six pts were treated with the F-MACHOP regimen, the other 7 according to a sequential acute lymphoblastic leukemia-type protocol (ALL0288). The BAVC regimen was used prior to ASCT. Fifty-five percent (35/63) of the pts achieved CR after CHT, 65\% (41/63) after CHT + RT, $87 \%$ (55/63) after CHT \pm RT + ASCT. Overall survival (OS) is $96 \%$ at 54 months (15-105); disease free survival (DFS) is $98 \%$ at 40 months (10-99). Comparing the observed results with those expected if pts were treated with CHT only, the sequential treatment including ASCT confered an advantage in terms of CR rate of $8 \%, 9 \%, 10 \%, 32 \%$, in the L, L-I, H-I, and $\mathrm{H}$ risk group respectively. The 2 year OS advantage is $10 \%, 16 \%, 26 \%$ and $63 \%$ in the four risk group respectively, and the 2 year DFS advantage is $12 \%, 20 \%$, $22 \%$ and $39 \%$ respectively. Our data confirm that ASCT performed in first $\mathrm{CR}$ or PR confers an advantage in terms of CR rate, OS and DFS for all the risk groups of the IPI and this advantage is greater as the risk increases. Consolidation with ASCT is a safe approach but since many patients who are autografted at or before first $\mathrm{CR}$ may be already cured, a clear definition of high-risk disease is mandatory.

\section{0}

\section{NORDIC MANTLE CELL LYMPHOMA (MCL) PROTOCOL: PRELIMINARY RESULTS OF PRIMARY PURGED AUTOLOGOUS PERIPHERAL BLOOD-STEM- CELL TRANSPLANTATION (PBSCT). $\mathrm{CH}$ Geisler, NS Andersen, E Elonen, A Johnson, A Kolstad for the Nordic Lymphoma Group.}

In mantle cell lymphoma (MCL) it has been shown that purging by complement mediated lysis failed to eradicate tumor cells from the patients (Andersen NS et al, Blood 1997;90:4212) Other purging methods (immunomagnetic beads and affinity columns) are presently being investigated. The Nordic multicentre MLC Protocol of HDT and purged or unpurged PBSCT focuses on the correlation between clinical outcome and the No. of tumor cells reinfused with the with the graft, based on quantitative PCR for either rearranged bcl-1 or CDR3. Results: Of 18 patients accrued, 11 have completed induction treatment ( 3 cycles of maxi-CHOP), and stem-cell harvest. 10 patients have proceeded to HDT (typically BEAM) and PBSCT. Nine patients were evaluable 2 months posttransplant. CR: 8 (all still PCR+), PD: 1. Seven patients received CD34+ selected grafts (CellPro) with a mean CD34+ cell purity of $65 \%$. The median tumor cell count $/ \mathrm{kg}$ body weight of these grafts was 22 (range 11-37) $\times 10^{3}$. Three CD34+ selected grafts were further CD34+ purified in laboratory-scale to $>98 \%$ CD $34+$ cell purity. One sample of such highly purified cells were further CD19+ cell depleted and became PCR-negative. Preliminary conclusions: HDT and ASCT leads to CR in most patients, but many tumor cells are reinfused with the graft in spite of CD34+ selection. Purging of the graft to $<10^{-6}$ tumor cells is possible.

\section{1}

MEGA-CHOEP: A DOSE ESCALATED CHEMOTHERAPY PROTOCOL WITH REPEATED STEM CELL SUPPORT FOR PRIMARY TREATMENT OF AGRRESSIVE NON-HODGKIN'S LYMPHOMA (NHL)

B. Glass, M. Kloess, L. Trümper, M. Pfreundschuh, A. Franke, G. Schlimok, R. Haas, M. Loeffler N. Schmitz. Kiel, Leipzig, Homburg, Magdeburg, Augsburg, Heidelberg for the German High Grade NHL Study Group.

The results of conventional high-dose therapy as primary treatment of aggressive NHL are equivocal. We tested the feasibility of a four cycle chemotherapy protocol including stem cell support after cycles 2-4 in a multicenter Phase $1 / 1 /$ dose escalating study. All patients with a newly diagnosed aggressive NHL, an age between 18-60 years and LDH at time of diagnosis above upper normal value were included. At dose level 1 , cycle 1 consisted of cyclophosphamide (CY) $1500 \mathrm{mg} / \mathrm{m}^{2}$, adriamycin (ADR) $70 \mathrm{mg} / \mathrm{m}^{2}$, vincristine $2 \mathrm{mg}$, Etoposide (ETO) $450 \mathrm{mg} / \mathrm{m}^{2}$, and prednisone $500 \mathrm{mg} / \mathrm{m}^{2}$. In subsequent cycles $\mathrm{CY}$ and ETO were intensified: Cycle II and III : CY $4500 \mathrm{mg} / \mathrm{m}^{2}$ and ETO $600 \mathrm{mg} / \mathrm{m}^{2}$, cycle IV: CY $6000 \mathrm{mg} / \mathrm{m}^{2}$ and ETO $1000 \mathrm{mg} / \mathrm{m}^{2}$. At dose level 2 ETO was further intensified throughout all 4 cycles: $600,960,960$ and $1480 \mathrm{mg} / \mathrm{m}^{2}$, respectively. From February 97 to November 98,74 patients were enrolled in the study, 44 at dose level 1 and 30 at dose level 2 . An interim analysis on the basis of 66 evaluable patients was performed in September 98 . Dose limiting non-hematologic toxicity was not observed, treatment related mortality did not occur. Sufficient numbers ( $>2 \times 10^{6} \mathrm{CD} 34+$ cells / $\mathrm{kg}$ BW) of PBPC could be obtained in all patients for all scheduled cycles of stem cell support. From start of cycle 1-4 recovery of the leukocytes ( $>1 /$ nl) needed $12,13,14$ and 15 days, respectively, recovery of the platelets (> $80 / n l) 13.5,16,16$ and 21 days (medians). The median time intervals between cycles were as follows: 1 to 2: 16 days, 2 to $3: 20$ days, 3 to 4 : 24 days. Compared to a conventional-dosed 21 day CHOEP protocol, the dose intensity of $\mathrm{CY}$ was 6 -fold and of ETO was 2.6 fold increased. We conclude that the application of the MEGA-CHOEP protocol is feasible for primary treatment of aggressive NHL and allows a substantial dose escalation of drugs known to be active in this disease. MEGA-CHOEP will be included in future randomised studies for such patients. 
FRONT-LINE HDC WITH CD34+ SELECTED PBSC FOR MANTLE CELL LYMPHOMA (MCL) - NO SUGGESTION OF SIGNIFICANT IMPROVEMENT OF DFS BY PURGING A SINGLE CENTER EXPERIENCE. P. Jindra, V. Koza, P.Cetkovský, P. Škopek, M. Švojgrová. Dept. Haematol/Oncol, Charles Univ.Hospital, Plzeň, Czech Republic.

Patients (pts) with MCL are rarely cured with standard therapy median survival is $24-36$ months (mo) and early relapses occur inevitably. Front-line intensification with HDC and autografting showed encouraging results on early follow-up. However frequent $\mathrm{BM}$ involvement raised concern of graft contamination We report experience with $\mathrm{HDC}$ and purged PBSC in order to intensify $1^{\text {st }}$ line therapy and to minimize graft contamination. From $6 / 95$ to $8 / 98,7$ pts with MCL were treated; $5 \mathrm{M} / 2 \mathrm{~F}$, median age 46 (37-52) years. All received anthracyclines-based conventional chemotherapy (CCT). PBSC mobilisation: CPA $3 \mathrm{~g} / \mathrm{m}^{2}+\mathrm{G}-\mathrm{CSF}$ and then immunoselection (Ceprate, CellPro). Conditioning regimen: BEAM. After CCT 1 pt achieved CR, 6 pts PR only with residual BM involvement. Median CD34+ counts pre- and post selection were $7.39 \times 10^{6} / \mathrm{kg}(5.75-19.15)$ and $3.11 \times 10^{6} / \mathrm{kg}(2.07-5.12)$, respectively. All pts promptly and completely engrafted with no transplant-related mortality and all achieved CR after transplantation (Tx). With a median follow-up of 22 (2-39) mo from Tx, 3 pts (43\%) have relapsed at a median time of 12 mo (3-25) after Tx, $1(14 \%)$ of them have died of disease. Thus 4 pts $(57 \%)$ remain in CR and $6(86 \%)$ are alive (OS $=86 \%$ and DFS $=57 \%$ at $22 \mathrm{mo}$ ). Conclusion: Although with short follow-up, our small group of pts confirms 1 . feasibility and safety of strategy 2 . possible OS benefit with $1^{\text {st }}$ line HDC. 3 . On the other hand the minimization of graft contamination by CD34+ selection does not seem to translate into the improvement of DFS comparing to results without purging.

\section{4}

LEUKEMIC PHASE OF ANAPLASTIC LARGE CELL LYMPHOMA AFTER AUTOLOGOUS STEM CELL TRANSPLANTATION. I Kardum-Skelin, D Sustercic, H Minigo, A Planinc-Peraica, S Ostojic, R Vrhovac, D RadicKristo, $\mathrm{K}$ Maric-Besic, O Jaksic, MM Kardum, B Jaksic. Department of Medicine, University Hospital "Merkur", Zagreb, Croatia.

We report an unusual case of a 40-year old patient with inguinal lymphadenopathy $(8 \mathrm{~cm}$ in diameter) who was admitted to our hospital in January 1994. Histological examination of lymph nodes revealed anaplastic large-cell lymphoma (Ki-1), bone marrow aspirate showed hypercellularity without neoplastic cells and peripheral blood was normal. He was treated with chemotherapy and complete remission was achieved. Patient first relapsed in July 1996 and again in July 1997 with palpable nodes on right arm. In November 1997 he was treated with BEAM myeloablative chemotherapy followed by autologous stem cell rescue. Both buffy coat from bone marrow harvest and peripheral blood after mobilisation did not show any evidence of characteristic neoplastic cells. Complete remission was achieved. However, the patient relapsed in March 1988 with fever and right axillar lymphadenopathy. Peripheral blood analysis revealed anemia, thrombocytopenia and hyperleucocytosis $\left(109 \times 10^{9} \mathrm{~L}\right)$ with 39 percent of characteristic anaplastic large cell lymphoma cells (peripheral blood and bone marrow CD 30 and ALCL markers positive, CD3, CD20 and CD15 negative). Abnormal metaphases were found in bone marrow (karyotype: $47, \mathrm{XY},+1$, $+2, \mathrm{t}(3 ; 6)(\mathrm{q} 27 ; \mathrm{p} 1),-5$, del $(13), \mathrm{t}(5 ; 13)(\mathrm{q} 11 ; \mathrm{q} 32)$, del 18p). Patient died of sepsis. Leukemia of anaplastic large cell lymphoma is an exceedingly rare event, only few cases have been reported so far. The relation to bone marrow and peripheral stem cell transplantation remains unclear.
HIGH DOSE THERAPY WITH AUTOLOOUS STEM CELL TRANSPLANTATION IN AGGRESSIVE NHL: TWO-YEARS RESULTS OF A RANDOMIZED STUDY. U.Kaiser, I.Uebelacker, K. Havemann on behalf of the German High Grade Lymphoma study group. Marburg, Germany

312 patients with primary high grade NHL aged $<60$ having the risk factor serum LDH >normal level and stages II-IV were included in a randomized multicenter study of the German high grade lymphoma study group from 1991-1997. Pts received either 5 cycles of CHOEP (CHOP+etoposide $3 \times 100 \mathrm{mg} / \mathrm{m}^{2}$ ) followed by involved field (IF) radiotherapy [A] or 3 cycles of CHOEP followed by autologous stem cell transplantation with BEAM followed by IF radiation [B] (in case of response after $2 \times C H O E P)$. Among 131 pts randomized to arm B, $67 \%$ received high dose therapy (HDT). In 14\% HDT could not be performed due to lack of response after 2xCHOEP. Median duration of neutropenia was 10 days, of thrombocytopenia 11.5 days. Transplant-related mortality was 0 . Overall survival for the 312 pts is $66 \%$ after two years, $68 \%$ for arm $A, 64 \%$ for arm $B(p=0.56)$. Event free survival is $58 \%$ in arm $A$ vs $62 \%$ in arm $B(p=0.41)$. Relapse in arm $B$ was associated with a significant worse survival than relapse in am $A(p<0.05) .26$ pts received HDT for progressive disease or relapse (in arm A) with a two year survival of $40 \%$. Relapse after HDT occured early with a median interval of 3 months.

HDT was performed without treatment related mortality. After two years there is yet no difference between both treatment arms.

\section{5}

INTENSIFIED VP 16 CONTAINING CONDITIONING REGIMEN FOLLOWED BY STEM CELL TRANSPLANTATION IN PATIENTS WITH NON-HODGKIN LYMPHOMA

N. Kröger, S. Sonnenberg , M. Hoffknecht, W. Krüger, M. Hänel, H. Renges, M.de Wit, HJ Weh, A. Krüll2 ${ }^{2}$, A.R. Zander

Bone Marrow Transplantation Center, Dept of Oncology/Hematology and ${ }^{2}$ Dept of Radiotherapy, University Hospital Hamburg-Eppendorf/Germany Objective:We investigate the toxicity and efficacy of an intensified conditioning regimen in 50 patients (pts) with relapsed or high-risk NonHodgkin lymphoma (NHL).

Patients and Methods: Fifty pts with a median age of 45 years (range: $19-$ 64) received high-dose chemotherapy (HDT) consisting of cyclophosphamide $(120 \mathrm{mg} / \mathrm{kg}$ ), etoposide $(30-45 \mathrm{mg} / \mathrm{kg}$ ) and either total body irradiation (TBI, 12Gy) $(\mathrm{n}=29)$ or busulfan $(16 \mathrm{mg} / \mathrm{kg})(\mathrm{n}=21)$ followed by peripheral stem cell support $(n=39)$, autologous $(n=6)$, allogeneic $(n=4)$ or syngeneic $(n=1)$ bone marrow transplantation. All but one had chemosensitive disease before HDT after a median number of 7.5 (range 4-15) cycles of previous chemotherapies. $16 \mathrm{pts}$ had received prior radiation therapy and 14 of them were treated with the $\mathrm{Bu} / \mathrm{Cy} /$ etoposide. There were $29 \mathrm{pts}$ with high-grade and 21 pts with low grade NHL according the Kiel-classification. 9 pts were in first CR, 2 in first PR, 38 pts had have more advanced disease.

Results: Main toxicity -according the Bearman score- was mucositis $\mathrm{II}^{\circ}$ in $78 \%$ and $\mathrm{I}^{\circ}$ in $20 \%$; hepatic toxicity $\mathrm{I}^{\circ}$ in $34 \%$ and $\mathrm{II}^{\circ}$ in $12 \%$; GI-toxicity $\mathrm{I}^{\circ}$ in $18 \%$ and $\mathrm{II}^{\circ}$ in $2 \% .32 \%$ of the pts developed transient erythema. $90 \%$ of the pts experienced FUO. The treatment-related mortality was $8 \%$ (2xVOD; $1 x$ Sepsis) Leucocyte $>1.0 / \mathrm{nl}$ and platelet $>20 / \mathrm{nl}$ was reached after a median of 11 (8-100) and 21 days (10-150),

respectively. One of the relapsing pts (Bu/Cy/VP16) developed secondary AML 18 months after transplant. After a median follow-up of 45 months (range 3-86) the 5years estimated disease-free and overall survival for all pts was 45 and $55 \%$, respectively. For relapsed high-grade NHL the DFS was $36 \%$ for the TBI group and $42 \%$ for the busulfan group.

Conclusion: Etoposide, cyclophosphamide and either TBI or busulfan is an active conditioning regimen with moderate toxicity in pts with relapsed or high-risk NHL. 
526

PURGED AUTOLOGOUS

ST EM

C E L L TRANSPLANTATION FOR 53 PATIENTS (pts) WITH FOLLICULAR NON HODGKIN'S LYMPHOMA (NHL): A SINGLE CENTER EXPERIENCE WITH BCL-2 MONITORING B. Mahé, MP Mellerin, N. Juge-Morineau, P. Moreau, JL Harousseau, N. Milpied. Dept. Hématologie, Centre Hospitalier Universitaire de Nantes, FRANCE.

From March 92 to November 1998, 53 patients with follicular NHL received autologous transplantation (AT) with purged stem cell grafts. Fourty-two pts were transplanted in first response and 11 in more advanced disease. For $30 \mathrm{pts}$, the graft consisted in B-cell depleted bone marrow (anti-B mo ab + complement or immunomagnetic beads). For $23 \mathrm{pts}$, the graft was CD34+ selected cells from mobilized peripheral blood progenitors cells. With a median follow-up of 47 months (7-79) $42 / 53$ pts are alive of whom 37 without disease progression. Fourteen pts relapsed a median of 6 months (2-56) after AT. Ten pts died, 9 from disease progression, one from myelodysplasia. Bcl-2 rearrangement was present (nested PCR analysis) in 30 of 53 pts at diagnosis. After B-cell depletion or CD34+ cell positive selection only 9 grafts were PCR negative. After AT, pts with Bcl-2 negative graft remained in CR in 7 cases for a median of 58 months (23-76), 6 remained $\mathrm{Bcl}-2$ neg, reapparition of Bcl-2 positivity was observed in 3 pts of whom 2 relapsed. Out of 21 pts with $\mathrm{Bcl}-2$ positive grafts, 14 are alive in CR, 7 relapsed, 4 pts were not reevaluated for $\mathrm{Bcl}-2$ : PCR became negative in 10 pts from 3 to 18 months post AT, 7 pts remained in CR for a median of 44 months (20-70), 3 relapsed $(10,11$ and $24 \mathrm{mo})$, reapparition of $\mathrm{Bcl}-2$ was observed in 1 of them. Seven pts with Bcl-2 positive graft remained $\mathrm{Bcl}-2$ positive, 5 remained in $\mathrm{CR}$ for a median of 56 months (12-77), 2 relapsed at 12 months.

Overall with $37 / 53$ pts alive and well a median of 47 months after AT, AT with purged graft appears to be effective. At present time, the monitoring of $\mathrm{Bcl}-2$ rearrangement does not allow to predict the outcome. Longer follow-up and larger number of pts is needed.

\section{8}

\section{HIGHDOSE-CHEMOTHERAPY WITH AUTOLOGOUS PBSCT AND HYPERFRACTIONED RADIOTHERAPY WITHIN FIRST-LINE TREATMENT FOR PRIMARY NHL OF THE CNS}

R. Marks, P. Warnke*, R. Guttenberger**, J. Slanina**, R. Mertelsmann, J. Finke. Depts. of Hematology and Oncology, *Stereotactic Neurosurgery and **Radiotherapy, Medical Center University Freiburg, D-79106 Freiburg

Primary NHL of the CNS (PCNSL) are mainly of B-cell origin and have a dismal prognosis despite initial response to steroids or radiotherapy. Treatment with combination chemo-/radiotherapy according to DeAngelis et al. (JCO 10:635,1992) improves relapse free- and overall-survival but shows significant late neurotoxicity, mainly due to post-radiation chemotherapy. To improve relapse free survival and reduce neurotoxicity we initiated a pilot study with early dose intensified chemotherapy with PBSCT followed by hyperfractioned whole-brain radiotherapy. The treatment regimen included repetitive cycles of high-dose MTX $(8000 \mathrm{mg} / \mathrm{m} 2), \operatorname{AraC}(3000 \mathrm{mg} / \mathrm{m} 2)$ and Thiotepa $(40 \mathrm{mg} / \mathrm{m} 2)$, followed by G-CSF mobilised stem cell harvest. $\mathrm{BCNU}(400 \mathrm{mg} / \mathrm{m} 2)$ and Thiotepa $(10 \mathrm{mg} / \mathrm{kg})$ were used for conditioning prior to PBSCT followed by hyperfractioned whole-brain radiotherapy ( $45 \mathrm{~Gy}, 2 \times 1 \mathrm{~Gy} /$ day) as consolidation Until now three out of four patients $($ age $<65)$ showed complete remission after chemotherapy (two without high-dose Thiotepa), or completion of the whole protocol, respectively. No severe toxicities (WHO Grade 3 or 4) were observed, apart high-dose treatment induced cytopenia. One patient showed no response to MTX treatment and was referred to radiotherapy directly. Firstline high-dose chemotherapy produces complete remission with acceptable toxicities in PCNSL.
UPFRONT HIGH-DOSE CHEMOTHERAPY WITH PBPCT IN HIGH-RISK, AGGRESSIVE NON-HODGKIN'S LYMPHOMA: A SINGLE CENTER EXPERIENCE

M. Manz, W. Brugger, F. Mayer, S. Auffermann, S. Scheding, B Dohmen*, R. Bares* and L. Kanz. Dep. of Hematology/Oncology *Dep. of Nuclear Medicine, University of Tübingen, Germany Patients with aggressive NHL who are at high-intermediate or high risk for relaps according to the international prognostic index have an unfavourable prognosis with conventional chemotherapy. Although high-dose chemotherapy and autologous PBPCT seems to be promising in these patients, CHOP chemotherapy is still the "gold" standard. In April 1995, we initiated an ongoing prospective single center phase II study for patients with highintermediate or high-risk aggressive NHL including high-dose chemotherapy and PBPCT as first line treatment. Patients recieved 6 weeks oi VACOP-B, followed by two cycles of VIP-E (VP16 $500 \mathrm{mg} / \mathrm{m}^{2}$, ifosf. $4000 \mathrm{mg} / \mathrm{m}^{2}$, cispl. $50 \mathrm{mg} / \mathrm{m}^{2}$, epir. $50 \mathrm{mg} / \mathrm{m}^{2}$ ) chemotherapy and G-CSF tratment for subsequent PBPC collection. Up to now, 26 patients were included in this protocol $(\mathrm{n}=6$ high-risk, $\mathrm{n}=20$ high-intermediate risk). The median age was 43 years (range 18-58), the median number of $\mathrm{CD} 34^{+}$cells was $5,8 \times 10^{6}$ (range $\left.2-10 \times 10^{6} / \mathrm{kg}\right)$. Responding patients $(\mathrm{n}=24 / 26$ $[92 \%] ; \quad C R=29 \%, \quad P R=71 \%$ ) recieved $B E A M$ consolidation chemotherapy followed by autologous PBPCT. Positrone-emission tomography (PET) was performed prior to high-dose chemotherapy and was negative in $64 \%$, while $42 \%$ of the patients were still weakly positive. After high-dose chemotherapy, $80 \%$ of the patients were PET negative. Patients with bulky disease $(n=18)$ recieved radiation as further consolidation treatment. With a median follow-up of 14 month (3-41), the DFS was $83 \%$ with an OS of $91 \%$. These results are comparable to published phase II trials evaluating high-dose chemotherapy as part of first-line treatment in aggressive NHL. Further follow-up will be presented

\section{9}

CHEMOTHERAPY IN AGGRESSIVE NHL WITH PARTIAL RESPONSE TO FRONT LINE CHEMOTHERAPY: LONG TERM RESULTS OF A RANDOMIZED ITALIAN MULTICENTER STUDY M. Martelli, M. Vignetti, P. Zinzani, C. Guglielmi, F. Gherlinzoni, G. Meloni, V. De Sanctis, M. Fiacchini, M. Cantonetti, S. Tura, F. Mandelli for the Italian NHL Cooperative Study Group.

We report long-term results of a prospective randomized multicentric study on the efficacy of a conventional salvage chemotherapy (DHAP) versus an high-dose chemoptherapy (BEAC) followed by autologous $\mathrm{BM}$ transplantation (ABMT) in patients with aggressive $\mathrm{NHL}$ in clinical partial or slow response after a conventional front-line chemotherapy. From August 1988 to 1991, 286 patients with aggresive NHL were enrolled from 7 italian centres. Firstly patients were randomized to receive either F-MACHOP or MACOP-B. Out of 286 pts, 77 (27\%) were considered in PR after two-third of the front-line chemotherapy and 49 of them $(44 \%)$ were randomized to receive DHAP (27 pts) or ABMT (22 pts). Results analyzed as of August 1994, already published (JCO 14:534-42, 1996), did not show any significant difference between the 2 arms, with an OS of $59 \%$ vs $73 \%$ and a PFS of $52 \%$ vs $73 \%$ in the DHAP and in the ABMT arm respectively. Neither major toxicities nor treatment related deaths occurred in both groups. As of March 1998, after a minimum follow up of 7 years, updated results shows, in the ABMT and in the DHAP groups respectively, a PFS of $68 \%$ versus $48 \% \quad(p=0.07)$ and an OS of $64 \%$ versus $55 \%(p=N S)$. Also after a longer follow up this study shows only a trend, not statistically significant, in favour of ABMT, thus definitively failing to reach the main objective of the protocol. This may also be due to the small number of pts randomized and to the lack of a more accurate procedure for PR evaluation. However, ABMT showed to be a safe and well tolerated procedure as early intensification and new ongoing trials should be encouraged in this setting of patients. 
BEAM MYELOABLATIVE CHEMOTHERAPY FOLLOWED BY AUTOLOGOUS STEM CELL RESCUE IS AN EFFECTIVE SALVAGE THERAPY FOR PATIENTS WITH MALIGNANT LYMPHOMA. $H$. Minigo, R. Vrhovac, A. Planinc-Peraica, I. Kardum-Skelin, S. Ostojic, D. Radic-Kristo, Z. Siftar, O. Jaksic, M. Strauss-Patko, C. Maglov, B. Jaksic. Department of Medicine, University Hospital "Merkur", Zagreb, Croatia

Several pre-transplant conditioning regimens are currently being used prior to autologous stem cell rescue in patients with malignant lymphoma. Our earlier results achieved with BEAM chemotherapy encouraged us to proceed with safety/effectiveness study of this conditioning regimen, this time specifically focusing on the subgroup of pretreated lymphoma patients with active disease. Fifty one pretreated patients with active lymphoma received BEAM chemotherapy followed by autologous stem cell rescue. There were 31 male and 20 female patients with a median age of 36 (range 18-63). Thirty one patients had Non-Hodgkin's lymphoma and 20 patients had Hodgkin's disease. All patients were heavily pretreated receiving a median of 2 different lines of chemotherapy (range 1-6) and a median of 8 chemotherapeutic cycles (range 2-31). An average of 4.70 (range 0.79-20.9, SD 4.89) $\times 10^{6} / \mathrm{kg}$ CD $34+$ cells was reinfused, MNC averaging 2.69 (range $0.53-11.35$, SD 2.02$) \times 10^{8} / \mathrm{kg}$. G-CSF $(5 \mu \mathrm{g} / \mathrm{kg})$ was administered during the leukopenic period to all but one patient (mean 10 days, range 6-22). This resulted in a median duration of leukopenia $\left(<1 \times 10^{\circ} / \mathrm{L}\right)$ of 9 days and a median of 4 febrile days (range $0-20$ ). Median time to WBC recovery $\left(>1 \times 10^{9} / \mathrm{L}\right.$ ) was 11 days post transplant (range 6-20). Median time to platelet recovery $\left(>20 \times 10^{9} / \mathrm{L}\right)$ was 14 days (range 6-30). During the cytopenic period patients were supported with an average of 19 platelet doses (range 6-77, SD 15.18) and an average of $561.4 \mathrm{~mL}$ of RBC concentrate (range $0-2410, \mathrm{SD}$ 541.1). As many as 23 patients (45.1\%) did not require any $\mathrm{RBC}$ transfusions. CR was obtained in $32(62.7 \%)$ and $\mathrm{PR}$ in $15(29.4 \%)$ patients. Transplant related mortality was $5.9 \%$. Projected overall survival from transplantation was $62 \%$ at 5 years, projected DFS was $67 \%$ at 5 years. In conclusion, BEAM myeloablative chemotherapy followed by autologous stem cell rescue induced high response rates, durable remissions and low transplant related mortality. Thus, the treatment proved to be both safe and effective even in this subgroup of heavily pretreated lymphoma patients.

\section{2}

AUTOLOGOUS STEM CELL TRANSPLANTATION (ASCT) IN NON HODGKIN'S LYMPHOMA (NHL): A SINGLE CENTER EXPERIENCE. F. Narni, A. Donelli, R. Sabbatini, G. Longo, R. Marasca, M. Savarino, V. Silingardi and G. Torelli. Department of Medical Sciences, Hematology and Oncology Section, University of Modena, Italy

Between June 1995 and October 1998, 52 patients affected by NHL have been treated with high-dose chemotherapy (HD-CHT) and ASCT in our Department. Median age was 43 years (range $15-65)$; 40 patients $(77 \%)$ had intermediate/high-grade NHL (EF-G-H-I-J, Working Formulation); $44(85 \%)$ had stage III/IV disease; $34(65 \%)$ had bulky disease; bone marrow involvement was present in $19(36 \%)$. Six patients were in second remission, whereas 46 were at diagnosis and received HD-CHT as a consolidation after a front-line treatment with anthracyclinebased regimens (CHOP in most cases). PBPCs were mobilized with cyclophosphamide ( $4 \mathrm{gr} / \mathrm{sqm})+\mathrm{G}-\mathrm{CSF}$. HD-CHT consisted of carmustine, etoposide, cytarabine and melphalan (BEAM) for 41 patients. The median follow-up is 21 months (1-42) from transplant and 30 months (8-52) from diagnosis. Eight patients $(15 \%)$ relapsed after ASCT. Seven patients died: 6 because of disease progression $(11.5 \%)$, and $1(1.9 \%)$ for treatment related complications (sepsis on day +4$)$. Forty-two patients $(81 \%)$ are alive in remission. The 3 -year estimated event-free survival (EFS) for the entire cohort and for patients at diagnosis is, respectively, $78 \%$ (95\% CI: $67-89)$ and $80 \%$ (95\% CI: $69-91)$. These data confirm that ASCT is a relatively safe procedure. The best results ( 3 years estimated $\mathrm{EFS}=93 \%$ ) are obtained in Blineage NHLs (mantle-cell lymphoma excluded) at diagnosis Although a larger number of patients is necessary, our data suggest a higher relapse risk for mantle-cell lymphoma (2/6) and T-cell NHLs (4/11).
A RAPID AND EFFECTIVE DEPLETION OF B CELLS USING CD19 AND CD20 MONOCLONAL ANTIBODIES COUPLED TO HIGH DENSITY MICROPARTICLES (HDM). H Houde, R Schmittling, T Lu, J Ritz, R Monroy. Coulter Cellular Therapies, Inc, Medford MA and Dana-Farber Cancer Institute, Boston, MA, USA.

Contamination of stem cells with residual tumor has been associated with a high incidence of relapse in patients with nonHodgkins lymphoma undergoing autologous stem cell transplantation. Effective purging of tumor cells may improve the results of autologous stem cell transplantation but current methods for purging result in loss of desirable stem/progenitor cells and inappropriately deplete T-cells and accessory cells, while not consistently eliminating all detectable tumor cells. We have developed a rapid and effective gravity sedimentation method for depletion of CD19 and CD20 positive B cells from concentrated peripheral stem cell pheresis products. The process utilizes $\mathrm{B} 4$ (CD19) and B1 (CD20) monoclonal antibodies coupled to high density microparticles (HDM). High cell concentration stem cell pheresis products $(\mathrm{n}=4)$ containing $2.6-4.4 \times 10^{10}$ nucleated cells were diluted to $220 \mathrm{ml}$ with simultaneously collected autologous plasma. Four cycles of HDM processing, requiring 10 minutes for conjugation and settling, depleted B cells (mean frequency $8.1 \%$, range $5.6 \%-13.2 \%$ ) by $\geq 4$ logs in all samples with immunocytochemical staining. CD34+ cell recoveries averaged $90.6 \%$ (range 80\%-99\%). CD4+ and CD8+cell recoveries averaged $86.8 \%$ (range $82 \%-94 \%$ ) and $87.5 \%$ (range $80 \%-97 \%$ ), respectively. These results demonstrate that anti-CD19 and CD20 antibodies coupled HDM routinely deplete $\geq 4$ logs of B target cells in $<60$ min without depleting non-target cells. Further studies will evaluate the purging of B cell tumor cells from autologous stem cells in patients with non-Hodgkins lymphoma.

\section{3}

DHAP MOBILIZED PBPC AUTOTRANSPLANTATION AS SALVAGE THERAPY IN HIGH GRADE NHL A. Olivieri D. Capelli, D. Massidda, M. Montanari, A. Poloni, R. Centurioni*, I Cantori, M. Lucesole, P. Leoni. Department of Hematology Ancona University, Italy ;* Department of Medicine Civitanova Marche, Italy.

We studied the efficacy of DHAP regimen followed by PBPC autologous transplantation in 23 consecutive patients affected by High Grade Non-Hodgkin's lymphomas. The age adjusted International Prognostic Index was 1 in 9 patients, 2 in 11 and 3 in 3 patients at diagnosis and all patients received DHAP regimen after failure (14 relapse, 2 Partial Remission and 7 Progression Disease) of first-line chemotherapy. The age ranged between 22 to 66 years (median 50); 10 were female and 13 male. All patients received DHAP regimen (median: 3 courses, range: 1-5) followed by G-CSF (Granulokine, Roche) at $5 \mu \mathrm{g} / \mathrm{kg} / \mathrm{day}$ until leukapheresis (LK). After DHAP chemotherapy 9 patients obtained CR, 7 a Partial Remission (PR) and 7 showed Progression Disease (PD). The PBPC collections were performed when the circulating CD34+ cell count was $>28 / \mu 1$ starting on day +13 as average (range: $11-18$ )

A median of $5(0.7-22) \times 10^{6} / \mathrm{kg}$ CD34+ cells and $48(7.3-208) \times$ $10^{4} / \mathrm{kg}$ CFU-GM was collected; afterwards patients received high-dose therapy (BEAM in 12 cases, Thiotepa-Melphalan in 6, MitoxantroneMelphalan in 3 and TBI+ ARA-C or CTX in 2 cases respectively). We observed one toxic death during the first 100 days for interstitial pneumonia; the engraftment was rapid and complete in all patients; the hemopoietic reconstitution was characterized by 11 days to reach neutrophils $>500 / \mu \mathrm{l} ; 14$ days to reach platelets $>20000 / \mu \mathrm{l}$ and 16 days to reach platelets $>50000 / \mu \mathrm{l}$; patients were generally discharged 15 days after the PBPC reinfusion. After transplantation 15 patients were in CR and 7 showed PD ; at present, with a median follow-up of 11 months (2-61), 9 pts are alive ( 8 in CCR, 1 in relapse) and 13 have died for recurrent lymphoma.

In conclusion the DHAP followed by G-CSF proved to be very effective in mobilizing PBPC after first line chemotherapy; the autotransplantation of DHAP+G-CSF mobilized PBPC is simple, cheap and effective and its overall toxicity was acceptable. Finally the effectiveness of the whole sequence in poor prognosis High Grade Non-Hodgkin's lymphomas is remarkable for obteining both the Complete Remission $(65 \%)$ and the Desease Free Survival (35\%). 
High-dose chemotherapy with autologous stem cells support in 2 patients with splenic marginal zone B-cell lymphoma and massive disseminated lung involvement. 'Papajik T., 'Faber E. ${ }^{\prime}$ Hubácek J., 'Raida L., ${ }^{2}$ MiXaniková M., ${ }^{2}$ Matuška M., ${ }^{3}$ Gumulec J., ${ }^{I}$ Urbanová R., 'Heczko M., 'Neoral C., ' Pikalová Z., 'D DuŠek J. a Indrák K. 1.Dpt.Haematooncology, Univ.Hospital, Olomouc, 2.Dpt.Haematology, Ostrava-Vitkovice, 3. Dpt.Haematology, Nový Jičín, 4.I.Surgery Dpt., Univ.Hospital, Olomouc, 5.Dpt.Pathology, Univ.Hospita! Olomouc; Czech Republic.

Splenic marginal zone lymphoma (SMZL) with or without villous lymphocytes has been accepted as the separate entity in the WHO classification of lymphoid tumors. Patients with this lymphoma typically have marked splenomegaly, bone marrow and peripheral blood lymphocytosis, M-component, but usually no peripheral lymphadenomegaly. The cells in some cases have typical villous morphology. The course is often indolent, but the aggressive variants have.short median survival.

We describe 2 females with the diagnosis of SMZL. Both had splenomegaly without lymphadenomegaly, bone marrow and peripheral lymphocytosis with typical immunophenotype, M-component (27,6 and $9,2 \mathrm{~g} / \mathrm{l}$, resp.) and massive disseminated lung involvement. The laboratory features ( $\mathrm{Hb}, \mathrm{LDH}, \mathrm{B} 2$ microglobulin) together with high IP indicated poor prognosis. Partial remission was achieved after the firstline chemotherapy (ProMACE-CytaBOM), but residual lung involvement outstayed. Thoracoscopic lung biopsy revealed a lymphoid infiltration of the parenchyma. Peripheral autologous stem cells were successfully collected after a salvage chemotherapy (HAM). The highdose regimen (BEAM) followed by infusion of stem cells $\left(4,3 \times 10^{9}\right.$ and $45,6 \times 10^{9} \mathrm{CD} 34+$ cells $/ \mathrm{kg}$, resp.) passed through without serious complications. Haematologic recovery was rapid (day +9 and +14 , resp.). One patient relapsed on day 100 post-transplantation and was treated aggressively (HAM, ESHAP) and now is in CR. The second patient achieved very good PR without signs of the disease excepting residual M-component ( $4 \mathrm{~g} / \mathrm{l}-85 \%$ reduction). Follow-up from the time of diagnosis is now 25 and 24 months, resp.

In conclusion, myeloablative high-dose chemotheraphy with autologous stem cells support could be beneficial for the patients with aggressive variants of the splenic marginal zone lymphoma.

\section{6}

COMPARISON BETWEEN TWO HIGH-DOSE THERAPY PROTOCOLS FOR TREATMENT OF LYMPHOMA. P.Pioltelli, M.Parma, P.Maffè, G.Corneo, EM Pogliani. Dept. Haematology - Marrow Transplant Unit. S.Gerardo Hospital. Monza.

We have treated $20 \mathrm{NHL}$ patients according to the High Dose Sequential Therapy ${ }^{1}$ (HDST) and autologous PBSC infusion after a debulking course with APO schedule (12 in Complete Remission and 8 in Partial Remission at conditioning), and 19 NHL patients with BEAM and autologous PBSC infusion after a debulking with CHOP+MAD schedule ${ }^{2}$ ( 9 in CR and 10 in PR at conditioning). All patients obtained marrow engraftment. In HDST group one patient had a myocardial infarction, in BEAM group one patient died for cardiac arrest and one patient died for VOD within 1 month after treatment. In HDST group all patients experienced grade 4 mucosytis instead in BEAM group only 2 patients did so. The time to reach $1 \times 10^{9} \mathrm{WBC} / \mathrm{L}$ was significantly shorter $(\mathrm{P}<0.002)$ in BEAM group for patients being in $P R$ at conditioning, and borderline $(P<0.04)$ for patients in CR. In HDST group 12 patients relapsed ( 8 in CR at conditioning), in BEAM group 5 patients relapsed ( 1 in CR). We found no difference between the treatments in time to reach complete hematological restitution, in the overall survival nor in time to relapse. We conclude that HDST and BEAM treatment are equivalent for survival but the patients treated with BEAM are less prone to mucosytis, and, possibly, to relapse.

References

1)Gianni AM, Bregni M, Siena S. et al. High dose chemotherapy and autologous BMT compared with MACOP-B in aggressive B-cell lymphoma. NEJM 1997, 336, 1280-1297

2)Cortelazzo S., Rossi A., Viero P. et al. BEAM chemotherapy and autologous haemopoietic progenitor cell transplantation as front-line therapy for high-risk patients with diffuse large cell lymphoma. Br.IHaematol 1997, 99, 379-385
DIFFUSE LARGE CELL LYMPHOMA (DLCL) : WHEN TO INTENSITY AND TRANSPLANT ? IE TO TRANSPLANT IN FIRST CR OR IN FIRST RELAPSE ? T.Philip, C.Sebban, P.Biron. Centre Leon-Berad, Lyon, France.

50 to $60 \%$ of DLCL are cured with chemotherapy. The international prognosis index is easy to use and the LNH trial has demonstrated a benefit for DLCL in CR when IPI 2 or 3 . The PARMA trial has demonstrated the benefit of auto BMT in 1 st or 2 nd chemosensitive relapses. There are no randomized controlled trial addressing the question : to transplant in first $\mathrm{CR}$ or in first relapse ?

177 patients with DLCL $\leq 60$ years at diagnosis (1985-1997) were reviewed and written interview were conducted in International expert team at London, Omaha, Houston, Roma, Amsterdam, Nantes, Paris and Lyon. Majors published papers in the literature were also reviewed. Results showed a median of $73 \% \mathrm{CR}, 6 \%$ early toxic death, $10 \%$ primary refractory and $11 \%$ partial response. $40 \%$ of $\mathrm{CR}$ who relapsed are eligible for BMT where survival is $50 \%$ for sensitive relapses and $5 \%$ for resistant relapses. Overall survival were also estimated per IPI score.

In summary for IPI 0,1 the first strategy (BMT in CR1) produced $68 / 100$ cures with 85 BMT. The second strategy (BMT after relapses) produced $64 / 100$ cures with only 10 BMT. For IPI 2 and 3,39/100 cures with 60 transplants or $33 / 100$ cures with 13 transplants are observed in the model. A prospective randomized study is mandatory to answer this very important question.

This work was partly supported by a grant PHRC 94 of the Ministry of Health.

\section{7 \\ ALLOGENEIC STEM CELL TRANSPLANT FOR LOW GRADE LYMPHOMA FOLLOWED BY ANTI-CD20 MONOCLONAL ANTIBODY FOR RESIDUAL DISEASE \\ AM Raiola, MT. Van Lint , G.Santini T. Lamparelli, F. Gualandi, D. Occhini, N. Mordini, G. Berisso, S. Bregante, R Oneto, B.Bruno, M Soracco, A Bacigalupo. Dipartimento di Ematologia, Ospedale San Martino, Genova, ITALY}

A 57 years old man, with NHL stage IV (CD19+, CD20+), underwent allo-PBSCT from his HLA identical sister, 8 years after diagnosis. Before BMT, several courses of chemotherapy (CHOP, HD CY, Flu, Flu/CY ) had produced only partial remissions of short duration. At BMT the problems were: bulky mediastinal and abdominal nodes, splenomegaly and moderate pancytopenia. Analysis by flow cytometry of bone marrow lymphocytes showed $30 \%$ to be $\mathrm{CD} 19+\mathrm{CD} 20+$. The patient was conditioned with Thiotepa $(8 \mathrm{mg} / \mathrm{kg})$ and Cyclophosphamide $(80 \mathrm{mg} / \mathrm{kg})$. GVHD prophylaxis consisted of CS and short course of MTX. The patients was infused with unmanipulated peripheral blood cells $\left(14 \times 10^{8}\right.$ cells $\left./ \mathrm{Kg}\right)$ and developed acute GvHD grade II and limited chronic GvHD.- On day +48 chimerism by DNA polymorphism analyisis showed $85 \%$ donor cells, but prolonged thrombocytopenia required a second infusion of CD34 selected allo-PBSC on day +220 .

Despite significant reduction of the mediastinal and abdominal nodes, flow cytometry of BM cells showed an increase of B lymphocytes $(\mathrm{CD} 19+, \mathrm{CD} 20+)$, up to $70 \%$ on day +250 . We then treated this patient with 4 doses of anti CD20 antibodies (Rituximab). A rapid reduction of $\mathrm{CD} 20+$ cells first and of $\mathrm{CD} 19+$ cells afterwards, until complete remission, could be shown in the patient's bone marrow. The patient is now on day +410 after first allo-PBSCT in complete remission.

This case outlines some of the problems of donor marrow engraftment, donor marrow function and residual disease, after submyeloablative conditioning regimens. It also shows the feasibility of a multi-step approach in low grade lymphomas 
HIGH-DOSE CYCLOPHOSPHAMIDE FOLLOWED BY AUTOGRAFTING CAN IMPROVE THE OUTCOME OF RELAPSED OR RESISTANT NON-HODGKIN'S LYMPHOMAS WITH INVOLVED OR HYPOPLASTIC BONE MARROW G. Gantini, C. De Souza, A.M. Congiu, G. Marino, S. Nati, E. Damasio. Department of Hematology, S. Martino Hospital, Genova, Italy.

We report our experience of high-dose cyclophosphamide(HDCY) followed by high-dose therapy (HDT) and peripheral blood progenitor cell (PBPC) autografting in aggressive non-Hodgkin's lymphomas who have failed conventional treatment. From 1991 to 1996, 54 consecutive patients pre-treated with a median of two chemotherapy lines entered the study. Eighteen patients $(33 \%)$ were still responders to conventional chemotherapy (sensitive relapse), and 20 patients (37\%) were in partial response (PR) after chemotherapy (CT). Sixteen patients $(30 \%)$ were resistant to conventional CT either ab initio (non responder) or in relapse (resistant relapse). Thirty-nine patients had bone marrow involved by disease and fifteen had hypoplastic marrow following conventional treatment. Patients received $\mathrm{HDCY}\left(7 \mathrm{gr} / \mathrm{m}^{2}\right)$ and G-CSF or GM-CSF in order to collect PBPC. Median collected CD $34^{+}$cells was $12.3 \times 10^{6} / \mathrm{Kg}$ (range 0.7 197). After HDT (BEAM or Melphalan + TBI) 50 patients underwent PBPC autografting. According to the intention to treat, $44(81 \%)$ out of 54 patients achieved complete remission (CR) $(50 \%$ after $\mathrm{HDCY}$ and $31 \%$ after HDT)

\begin{tabular}{lrrrr} 
Status & Pts $\left(\mathrm{n}^{\circ}\right)$ & $\mathrm{CR}$ after HDCY & $\mathrm{CR}$ after HDT & \multicolumn{1}{c}{ final CR } \\
\hline PR & 20 & $11(55 \%)$ & $4(20 \%)$ & $15 / 20(75 \%)$ \\
Sens/Rel & 18 & $13(72 \%)$ & $4(22 \%)$ & $17 / 18(94 \%)$ \\
Res/Rel & 4 & $1(25 \%)$ & $2(50 \%)$ & $3 / 4(75 \%)$ \\
NR & 12 & $2(16.5 \%)$ & $7(58.5 \%)$ & $9 / 12(75 \%)$
\end{tabular}

Procedure related death occurred in 6 patients $(11 \%)$, one after HDCY and 5 after autografting. Twenty-nine $(66 \%)$ out of 44 patients are still in CR 7 to 63 months (median 27 months) after the procedure. Threeyear probability of survival, disease-free survival and progression-free survival are $63 \%, 64 \%$ and $52 \%$ respectively. In conclusion, $\mathrm{HDCY}$ is an effective procedure not only in mobilizing PBPC, but also in reducing tumour burden. HDT with PBPC support may further improve the outcome in this category of high-risk non-Hodgkin's lymphomas.

\section{0}

ALLOGENEIC TRANSPLANTATION WITH PBPC IS AN EFFECTIVE OPTION FOR RELAPSED/REFRACTORY NONHODGKIN'S LYMPHOMA. C Tarella, D Caracciolo, P Corradini, B Allione, A Novarino, T Van Lint, A Bacigalupo, F Locatelli, M Falda. Unità Trap Midollo, Az Osp S.Giovanni Battista, Torino, and Az Osp S. Martino, Genova - Italy

Intensive chemotherapy with high-dose (hd) drug administration is widely employed in advanced stage, non-Hodgkin's Lymphoma (NHL). Reduced autograft toxicity using PBPC compared to BM made this procedure considered in several hd programmes. Most patients seem to benefit from this approach either as primary or as salvage treatment. However, patients refractory or relapsing following hd-therapies have little if any chances and very short life expectancy. In order to evaluate the role of allogeneic transplant in this particular setting, we have analysed 16 patients undergoing allograft for progressive NHL. Their main clinical features were: median age: 36 (range 28-56); $M / F$ ratio: 9/7; histology subtypes: Burkitt's $=2$; diffuse large-cell $=5$; mantlecell $=3$; low-grade $=6$; disease status: $1^{\text {st }}$ relapse $=7 ; \geq 2$ nd relapse $=4$; $1^{\text {st }} \mathrm{PR}=3$; refractory lymphoma $=2$. All patients were allografted with PBPC from related donors. They were conditioned with a regimen including thiotepa and cyclophosphamide (generally at $15 \mathrm{mg} / \mathrm{kg}$ and $150 \mathrm{mg} / \mathrm{kg}$ total, respectively). Cyclosporin A and methotrexate were employed as GVHD prophylaxis. Rapid and sustained engraftment was observed in all patients; grade 2-3 aGVHD was recorded in 8 out of 15 evaluable patients, while cGVHD developed in 10 out of 13 evaluable patients. There were 2 treatment-related deaths; 3 more patients with high-grade NHL died for disease progression. At a median follow-up of 29 months (range 2-48) 11 patients are alive without signs of disease progression. In conclusion a salvage treatment with allogeneic PBPC transplant should always be offered to NHL patients progressing after intensive chemotherapy. This approach seems particularly effective in low-intermediate grade histologies.
VACOP/B, HIGH-DOSE CYTOXAN AND HIGH-DOSE THERAPY WITH PBPC RESCUE FOR AGGRESSIVE NHL WITH BONE MARROW INVOLVEMENT: CLINICAL AND PROGNOSTIC SIGNIFICANCE. G. Santini, AM. Congiu, A. Olivieri, P. Coser, C. Guarnaccia, I. Maiolino, T. Chisesi, P. Leoni, L. Salvagno, A. Porcellini, M.R. Sertoli, A. Rubagotti, V. Rizzoli for the Non-Hodgkin's Lymphoma Co-Operative Study Group. Department of Hematology, S. Martino Hospital, Genova, Italy.

Aggressive NHL with BM involvement at diagnosis has a poor prognosis. Survival probability at 3-years is about $20 \%$ using conventional chemotherapy. From 1992 to 1994 a study which included VACOP-B until maximum response followed by highdose cytoxan (HDCY) and PBPC autografting as front-line therapy in 40 successive patients (groups F-G-H-K/WF) was performed. Median age of patients was 51 yrs.(range 20-60); 25 were male and 15 female; median BM involvement was $35 \%$ (range $8 \%-90 \%$ ). Patients received a median of 8 VACOP-B courses, followed by HDCY $\left(7 \mathrm{gr} / \mathrm{m}^{2} /\right.$ single dose) plus G- or GM-CSF (5 $\mathrm{mcg} / \mathrm{Kg}$ ) to reduce tumour burden and collect PBPC. With a median number of 3 aphereses a median of $11.3 \times 10^{\wedge} 6 / \mathrm{Kg} \mathrm{CD} 34+$ cells were collected. Twenty-nine patients underwent PBPC autografting after Melphalan + TBI or BEAM regimen. According to intention to treat, $29 / 40$ patients $(72.5 \%)$ achieved CR: $10 / 40$ (25\%), after VACOP-B treatment; $8 / 40(20 \%)$, after HDCY; $11 / 40$ $(27.5 \%)$, after high-dose therapy. The statistical analysis shows a $3-$ year probability of survival of $47 \%$, with a probability of DFS and PFS of $50 \%$ and $37 \%$, respectively. A statistical analysis of morphology and extent of BM infiltrate, and clinical features according to the IPI, in terms of OS, DFS and PFS was performed. This analysis did not show any statistical factor predicting a poor outcome excluding the extent of BM infiltrate $>50 \%$ in terms of DFS $(P=.03)$. This study suggests that high-dose sequential therapy may improve the outcome of these patients. The extent of BM involvement identifies a group of patients with high risk of relapse.

\section{1}

USE OF MOBILIZED PBPC TO SUPPORT INTENSIFIED CHEMOTHERAPY IN ELDERLY NON-HODGKIN'S LYMPHOMA PATIENTS . C Tarella, F Zallio, P Gavarotti, L Bergui, D Caracciolo, A Cuttica, A Cucci, F Giaretta, A Pileri. Dip Med Oncol Sperim, Div Univ Ematologia, Az Osp S.Giovanni Battista, Torino - Italy

The use of mobilized peripheral blood progenitor cells (PBPC) is increasingly employed in the management of advanced-stage nonHodgkin's lymphoma (NHL) patients aged less than 60 yrs. However, its applicability in elderly patients has not been fully investigated yet. In order to verify PBPC mobilization, harvest and reinfusion in the elderly, we evaluated 18 pts. aged between 61 and 80 yrs. (median 68) undergoing intensified chemotherapy for advanced stage NHL. Main clinical features included: $M / F$ ratio 9/9; histologic subtypes: Burkitt's $=1$, diffuse large cell=7, mantle-cell=3, low/intermediate grade $=7 ; B M$ involvement $=11$; high $L D H=12$; Stage III-IV=17; Performance Status 3-4=16; disease status: at onset=12; at $1^{\text {st }}$ or subsequent relapse $=6$. Mobilization was induced by 3 different schedules, i.e. epirubicin $120 \mathrm{mg} / \mathrm{sqm}$ ( $2 \mathrm{pts}$.), cyclophosphamide $4 \mathrm{gr} / \mathrm{sqm}$ (13 pts.), etoposide $1.5 \mathrm{gr} / \mathrm{sqm}$ (3 pts.), all followed by G-CSF at $5 \mu \mathrm{gr} / \mathrm{kg} /$ day. Fourteen pts. displayed signs of progenitor mobilization, with median peak values of circulating $\mathrm{CD} 34+/ \mu \mathrm{L}$ and CFU-GM/ml ranging between 4-210 (median 23), and 45062,900 (median 1,416), respectively. PBPC were harvested by 1 to 3 leukaphereses (median 2), with a median collection of $\mathrm{CD} 34+/ \mathrm{kg}$ and $\mathrm{CFU}-\mathrm{GM} / \mathrm{kg}$ of $3.5 \times 10^{6}$ and $16.2 \times 10^{4}$, respectively. Harvested PBPC were then reinfused in 12 pts. following intensified chemotherapy. One pt. died for pneumonia following hd-ARA-C and autograft delivered for cerebral disease progression; no other fatal complication occurred either during mobilization or after PBPC reinfusion. An overall tumor response could be documented in 16 patients. Thus, the use of autologous $\mathrm{PBPC}$ is a feasible option for the management of elderly NHL. 